\title{
DÜBLIN
}

Technological University Dublin

ARROW@TU Dublin

\section{Effect of cold plasma on the techno-functional properties of animal protein food ingredients}

\author{
Juan M. Pérez-Andrés \\ Teagasc Food Research Centre \\ Carlos Álvarez \\ Teagasc Food Research Centre \\ Patrick Cullen \\ Technological University Dublin, pj.cullen@tudublin.ie
}

See next page for additional authors

Follow this and additional works at: https://arrow.tudublin.ie/schfsehart

Part of the Food Biotechnology Commons, Food Chemistry Commons, Food Microbiology Commons, Food Processing Commons, and the Other Food Science Commons

\footnotetext{
Recommended Citation

This Article is brought to you for free and open access by the School of Food Science and Environmental Health at ARROW@TU Dublin. It has been accepted for inclusion in Articles by an authorized administrator of ARROW@TU

Dublin. For more information, please contact

arrow.admin@tudublin.ie, aisling.coyne@tudublin.ie, gerard.connolly@tudublin.ie.

Funder: European Union
}

Juan M. Pérez-Andrés, Carlos Álvarez, P.J. Cullen, Brijesh K. Tiwari, Effect of cold plasma on the technofunctional properties of animal protein food ingredients, Innovative Food Science \& Emerging Technologies, Volume 58, 2019, 102205, ISSN 1466-8564, DOI: 10.1016/j.ifset.2019.102205.

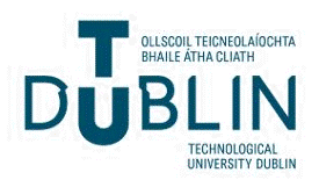




\section{Authors}

Juan M. Pérez-Andrés, Carlos Álvarez, Patrick Cullen, and Brijesh K. Tiwari

This article is available at ARROW@TU Dublin: https://arrow.tudublin.ie/schfsehart/432 


\title{
Effect of cold plasma on the techno-functional properties of animal protein food ingredients
}

\author{
Juan M. Pérez-Andrés ${ }^{\mathrm{a}, \mathrm{b}}$, Carlos Álvarez ${ }^{\mathrm{c}}$, P.J. Cullen ${ }^{\mathrm{b}, \mathrm{d}, *}$, Brijesh K. Tiwari ${ }^{\mathrm{a}}$ \\ ${ }^{a}$ Food Chemistry and Technology, Teagasc Food Research Centre, Dublin 15, Ireland \\ ${ }^{\mathrm{b}}$ BioPlasma Research Group, School of Food Science and Environmental Health, Technological University Dublin, Cathal Brugha Street, Dublin 1, Ireland \\ ${ }^{\mathrm{c}}$ Food Quality \& Sensory Science, Teagasc Food Research Centre, Dublin 15, Ireland \\ ${ }^{\mathrm{d}}$ School of Chemical and Biomolecular Engineering, University of Sydney, Sydney, Australia
}

\section{A R T I C L E I N F O}

\section{Keywords:}

Cold atmospheric plasma

Functional properties

Food proteins

Solubility

Emulsifying

Rheological properties

\begin{abstract}
A B S T R A C T
Proteins, as food ingredients, are employed in the food industry, not only for their high nutritional value, but also because of their techno-functional properties. Modifications of their native structure due to the action of external factors such as $\mathrm{pH}$, temperature or processing by emerging technologies, can lead to changes in their functionality; and consequently, their applicability. The present study investigates the effects of cold atmospheric air plasma on the techno-functional properties of two common food ingredients (haemoglobin and gelatine from pork), and a novel source of functional proteins extracted from a meat co-product (bovine lung protein). Significant effects were found for their functional, rheological and gelling properties. However, the effects were found to depend on the native structure and nature of the protein. The findings point to the specific nature of plasma-protein interactions and the need for individual proteins to be studied as a function of plasma conditions.

Industrial relevance text: Cold plasma is increasingly being investigated as a non-thermal technology for food and other biological applications such as primary agriculture and medicine. In addition to microbial and pest decontamination, it can be also be used to modify the functionality of food ingredients to achieve the desired properties of a specific food product.
\end{abstract}

\section{Introduction}

In recent years emerging non-thermal technologies, which operate under sub lethal temperature conditions, have been investigated for food decontamination including: high hydrostatic pressure (Huang, Wu, Lu, Shyu, \& Wang, 2017), ultrasound (Arvanitoyannis, Kotsanopoulos, \& Savva, 2017), pulsed electric fields (Barba et al., 2015), ozone (Cullen \& Norton, 2012), light emitting diodes (LED and ultraviolet (UV) (Li \& Farid, 2016) and cold atmospheric plasma (Bourke, Ziuzina, Boehm, Cullen, \& Keener, 2018). The main advantages of these technologies is that they operate at mild temperatures, which may prevent the loss of desired quality parameters which are commonly found with high temperatures such as degradation of colour (pigments), vitamins loss, texture modification, off-flavours and protein structure modifications (Awuah, Ramaswamy, \& Economides, 2007); as well as a potential reduction of energy consumption when compared to traditional processing techniques (Rodriguez-Gonzalez, Buckow, Koutchma, \&
Balasubramaniam, 2015). However, it has been found that these processing technologies may also negatively affect food components (Perez-Andres, Charoux, Cullen, \& Tiwari, 2018). For example, Xuan et al. (2018) found that high pressure promoted lipid oxidation, as well as a decrease in the content of myofibrillar proteins related to damage of the tertiary structure of fresh razor clams. Similar results were reported by Guyon, Le Vessel, Meynier, and de Lamballerie (2018), who described a modification of the quantity/number of amino acids in beef mince after pressurization, and an increase of protein oxidation. In the case of ultrasound, it was observed that processing significantly accelerated both lipid and protein oxidation. For instance, Italian salami oxidation of lipids and proteins were reported after 3 min treatment using an ultrasound bath at $25 \mathrm{kHz}$ (Alves et al., 2018). Moreover, oxidation of these food components in beef was also reported at all intensities (ranging from 2.39 to $20.96 \mathrm{~W} \mathrm{~cm}^{-2}$ ) and times studied (ranging from 30 to $120 \mathrm{~min}$ ) (Kang et al., 2016).

Proteins, as food ingredients, are employed in the food industry, not

\footnotetext{
* Corresponding author at: BioPlasma Research Group, School of Food Science and Environmental Health, Technological University Dublin, Cathal Brugha Street, Dublin 1, Ireland.

E-mail address: pjcullen@dit.ie (P.J. Cullen).
} 
only for their high nutritional values, but also because of their technofunctional properties. They are an important structural component of many foods, imparting key properties to the final product such as gelling properties, emulsifying ability or water and oil holding capacity. Modifications of their native structure, due to the action of external factors such as $\mathrm{pH}$, temperature or processing by emerging technologies, can lead to a change of their functionality; and consequently, the features of the food product where they are used as ingredients (Kristo, 2015). In this sense, emerging technologies can lead to protein modifications which potentially can modify protein functionality, for example enhanced solubility or emulsifying ability.

A review dealing with the effect of these novel technologies on the functional properties of food proteins (Mirmoghtadaie, Aliabadi, \& Hosseini, 2016), reports on the key effects for each of the most promising emerging technologies. For example, high hydrostatic pressure has been investigated to modify the functional properties of food proteins (Yang \& Powers, 2016). A faba protein solution $(1 \% \mathrm{w} / \mathrm{v}$ in $\mathrm{ul}-$ trapure water) was treated at 103 and $207 \mathrm{MPa}$ during 6 cycles, with a significant improvement in both solubility and foaming capacity found post treatment, however, the emulsifying capacity decreased (Yang, Liu, Zeng, \& Chen, 2018). In addition, sarcoplasmic proteins from hake were treated at 200, 400 and $600 \mathrm{MPa}$ for $6 \mathrm{~min}$, with the solubility decreasing significantly with increasing pressure. In contrast, an increase in the hydrophobicity was found as the applied pressure increased (Villamonte, Pottier, \& de Lamballerie, 2016). In another study, an improvement of solubility, foaming, emulsifying capacity and emulsifying stability of a hazelnut protein solution $(2 \% \mathrm{w} / \mathrm{v}$ in ultrapure water) after treatments at 25, 50, 75, 100 and $150 \mathrm{MPa}$ was reported (Saricaoglu, Gul, Besir, \& Atalar, 2018).

The impact of ultrasound on protein techno-functional properties has also been reviewed (O'sullivan, Park, Beevers, Greenwood, \& Norton, 2017). For example, a myosin extract from silver carp was treated using an ultrasound probe at $20 \mathrm{kHz}$ at variable intensities (from 100 to $250 \mathrm{~W}$ ) for several time periods (3, 6, 9 and $12 \mathrm{~min}$ ). After treatment, significant changes in the structure and the physicochemical properties of myosin were reported, such as an increase in its solubility and hydrophobicity (Liu, Liu, Xiong, Fu, \& Chen, 2017). The solubility and emulsifying capacity of a millet protein concentrate solution $(10 \%$ $\mathrm{w} / \mathrm{w}$ in ultrapure water) was also improved after 20,60 and $100 \mathrm{~W}$ treatment, for treatments of $5 \mathrm{~min}$ or more were applied, using a sonotrode probe (Nazari, Mohammadifar, Shojaee-Aliabadi, Feizollahi, \& Mirmoghtadaie, 2018). Solubility, emulsifying and water holding capacity in bull myofibrillar proteins increased significantly with increasing power and treatment time (Amiri, Sharifian, \& Soltanizadeh, 2018).

The use of pulsed electric fields (PEF), to modify food proteins has been reviewed by Giteru, Oey, and Ali (2017). Soy protein was treated using PEF, at different intensities ( 10 to $40 \mathrm{kV} / \mathrm{cm}$ ) applying pulses for times between 100 and 600 microseconds. Significant increases in the solubility and hydrophobicity of the treated samples were reported $(\mathrm{Li}$, Chen, \& Mo, 2007). However, a solubility decrease of egg white proteins was found with a constant electric field intensity of $25 \mathrm{kV} / \mathrm{cm}$, regardless of treatment time (Wu, Zhao, Yang, \& Chen, 2014).

Cold atmospheric plasma (CAP) is a partially ionised gas composed of reactive species such as photons, ions and electrons, which can interact with food components including food proteins. This interaction can lead to several types of reactions such as dimerization, oxidation, deamidation, nitration, sulfoxidation, dehydrogenation and/or hydroxylation of amino acids (Takai et al., 2014). CAP is an emerging nonthermal technology with potential applications for several different industries such as textile, medicine, biotechnology, electronic, as well as water and air purification (Kramer et al., 2015). As a potential food processing technology, recent research has demonstrated CAP's potential for food decontamination and shelf-life extension (Bourke et al., 2018). It is established that CAP can lead to oxidation and degradation of food components (Gavahian, Chu, Khaneghah, Barba, \& Misra, 2018;
Pankaj, Wan, \& Keener, 2018). However, limited research has been reported on whether this technology can affect, either positively or negatively on the functionality of food proteins. The small but growing literature on the topic has been review by Tolouie, Mohammadifar, Ghomi, and Hashemi (2017). For instance, peanut isolated protein was treated using plasma generated using a dielectric barrier discharge (DBD) system at $35 \mathrm{kV}$ over 1, 2, 3 and $4 \mathrm{~min}$; with a modification of its secondary structure found, leading to an improvement of its emulsion stability, water holding capacity and solubility (Ji et al., 2018).

The objective of this work is to assess the impact of CAP on the key functional properties of three model protein powders: gelatin, as partially hydrolysed protein; haemoglobin as an isolated and native protein and lung protein extract, as an example of an isolated protein blend. In addition, any conformational changes induced in the protein structure were monitored by means of surface hydrophobicity.

\section{Material and methods}

\subsection{Chemicals and reagents}

Hydrochloric acid, sodium chloride, sodium hydroxide, sodium phosphate monobasic sodium phosphate dibasic, Coomassie brilliant blue G and pork gelatine, were obtained from Sigma-Aldrich (Arklow, Co. Wicklow, Ireland). Rapeseed oil was purchased from a local market. Ultra-pure water $\left(18.2 \mathrm{M} \Omega \mathrm{cm}^{-1}\right)$ was generated in-house using a Millipore water purification system (Millipore, Cork, Ireland). Haemoglobin was obtained following the methodology described by Álvarez, Drummond, and Mullen (2018), while extraction of the lung protein was conducted as described by Lynch, Álvarez, O'Neill, Keenan, and Mullen (2018).

\subsection{Plasma treatment}

Forty grams of each protein were weighed and spread homogenously into polystyrene petri dishes $(150 \mathrm{~mm} \times 15 \mathrm{~mm})$. Each petri dish was placed between two aluminium plate electrodes (outer diameter $=158 \mathrm{~mm}$ ) separated by two polypropylene(PP) dielectric layers ( $2 \mathrm{~mm}$ thickness) forming a dielectric plasma barrier (DBD) reactor as described by Pankaj, Misra, and Cullen (2013). The discharge voltage was set at $80 \mathrm{kV}$ (RMS) with atmospheric air used as the inducer gas for a treatment time of $15 \mathrm{~min}$. During the treatment it was observed that protein powder was constantly in movement forming a cloud inside the petri dish. This movement helped to homogenise the sample. Control and plasma samples were kept at $4{ }^{\circ} \mathrm{C}$ for $24 \mathrm{~h}$ prior to analysis.

\subsection{Functional properties}

\subsubsection{Solubility}

The method reported by Penteado, Lajolo, and Pereiradossantos (1979) was used to study protein solubility. $0.5 \mathrm{~g}$ of the protein sample was added to $10 \mathrm{~mL}$ of milliQ water. Different $\mathrm{pH}$ solutions were prepared over the range of 3-8. After that, all solutions were centrifuged at $2400 \mathrm{~g}$ for $30 \mathrm{~min}$ at $4{ }^{\circ} \mathrm{C}$ in a Hettich Rotanta 460R centrifuge (Fisher Scientific Ireland, Dublin, Ireland). The amount of soluble protein in the supernatant was quantified by measuring absorbance at $280 \mathrm{~nm}$ using a ND-100 Nanodrop Spectrophotometer (Nanodrop Technologies, Wilmington, DE, USA). All the experiments were carried out in triplicate. The solubility was calculated as:

$\% S=\frac{P d}{P t} x 100$

where $\% \mathrm{~S}$ is the percentage of solubility, Pd is the amount of soluble protein $(\mathrm{g})$ and $\mathrm{Pt}$ the amount $(\mathrm{g})$ the total protein used in the assay.

\subsubsection{Emulsifying capacity}

Emulsifying capacity was determined by the Inklaar and Fortuin 
(1969) method. Solutions of different concentrations of protein sample in ultrapure water (containing 0.075 of $\mathrm{NaCl} \mathrm{w/v)} \mathrm{were} \mathrm{prepared}$ ranging from $2 \mathrm{mg} / \mathrm{mL}$ to $10 \mathrm{mg} / \mathrm{mL} \mathrm{NaCl}$ was added to increase the protein-emulsifying capacity because protein folding is induced. In the case of extracted lung proteins (ELP) the $\mathrm{pH}$ after dissolving in water was around 10, usually too high for emulsification to occur; consequently the $\mathrm{pH}$ was adjusted to 6 , using $1 \mathrm{M}$ hydrochloric acid $(\mathrm{HCl})$ solution. After that, $13 \mathrm{~mL}$ of rapeseed oil was added to each sample and mixed at $13500 \mathrm{rpm}$ for 2 min using a using an Omni Prep MultiSample Homogenizer (Omni International). Subsequently, samples were centrifuged at $1200 \mathrm{~g}$ for $10 \mathrm{~min}$ at $4^{\circ} \mathrm{C}$ in a Hettich Rotanta $460 \mathrm{R}$ centrifuge. The leftover oil not consumed during the emulsification process was weighed. Triplicates of all experimental results were obtained. The percentage of emulsification was calculated as:

$\% E=\left(1-\frac{g_{e} * \rho_{e}}{V \boldsymbol{a}}\right) x 100$

where $\% \mathrm{E}$ is the percentage of emulsification, $\mathrm{g}_{\mathrm{e}}$ the weight of the leftover oil $(\mathrm{g}), \rho_{\mathrm{e}}$ the density of rapeseed oil and Va the volume of the added oil (mL).

\subsubsection{Rheological and gelation properties}

The lowest gelation concentration (LGC) and gelation temperature (Tg) were studied for the three proteins. Melting temperature (Tmel) was also obtained for the gels formed using pork gelatine. LGC was analysed according to the approach reported by Coffmann and Garciaj (1977). Protein samples were prepared in water in a range of concentrations between 2 and $12 \%$ each stirred with a vortex stirrer and heated to $85^{\circ} \mathrm{C}$ over $30 \mathrm{~min}$. Subsequently, the samples were left to cool to $4{ }^{\circ} \mathrm{C}$ and stored overnight in a fridge to allow for the formation of a gel. The lowest gelation concentration was selected where a consistent gel was formed by examining their resistance to flow under gravity.

Rheological measurements were performed using a controlled stress rheometer (Anton Paar MCR 301, Anton Paar Gmbh, Graz, Austria) employing a parallel plate geometry (diameter $50 \mathrm{~mm}$ ) and a $1 \mathrm{~mm}$ gap. A solution containing a $10 \%(\mathrm{w} / \mathrm{v})$ of each protein was employed for analysis. To prevent evaporation, water was added to the top of the upper plate. Ten minutes were allowed to stabilize the sample at $20^{\circ} \mathrm{C}$ after the $1 \mathrm{~mm}$ gap was reached. Then, a gradient of temperature was applied, consisting of: $0-2.5 \mathrm{~min}$ at $20^{\circ} \mathrm{C}, 2.5-15 \mathrm{~min}$ covering a temperature ramp of $20-80^{\circ} \mathrm{C}, 15-20 \mathrm{~min}$ at a constant temperature of $80^{\circ} \mathrm{C}$ and $20-40 \mathrm{~min}$ over covering the temperature ramp of $80^{\circ} \mathrm{C}$ to $20^{\circ} \mathrm{C}$. Measurements were taken at a strain of $1 \%$ and a frequency of $1 \mathrm{~Hz}$. In the specific case of the pork gelatin, the solution was heated at $50{ }^{\circ} \mathrm{C}$ in a water bath for $10 \mathrm{~min}$ before the sample was loaded onto the rheometer. Depending on the nature of the protein the Tg could be determined by three methods. Firstly, the intersection point between the elastic/storage $\left(G^{\prime}\right)$ modulus and the viscous/loss modulus $\left(G^{\prime \prime}\right)$ (Lamsal, Jung, \& Johnson, 2007). If there is no line crossing between the parameters, the gelling temperature is obtained once the $\mathrm{G}^{\prime}$ modulus reaches a value of $1 \mathrm{~Pa}$. Finally, if neither of these two conditions occurs, the gelling temperature is determined as the temperature of the inflection point. Tmel was obtained where a second crossover occurred between the viscous/loss $\left(G^{\prime \prime}\right)$ and the elastic/storage moduli $\left(G^{\prime}\right)$.

\subsubsection{Water and oil holding capacity}

The water and oil holding capacities were determined according to the method of (Beuchat, 1977). The oil holding capacity was measured by adding $10 \mathrm{~g}$ of oil to $0.5 \mathrm{~g}$ of the protein sample and gently homogenised using a vortex stirrer. After resting for $30 \mathrm{~min}$, the mixture was centrifuged at $2200 \mathrm{~g}$ for $10 \mathrm{~min}$ at $4{ }^{\circ} \mathrm{C}$ in a Hettich Rotanta $460 \mathrm{R}$ centrifuge (Fisher Scientific Ireland, Dublin, Ireland). The same method was employed to measure the water holding capacity, except for replacing $10 \mathrm{~g}$ of oil with $10 \mathrm{~g}$ of ultra-pure water.

\subsubsection{Surface hydrophobicity}

The surface hydrophobicity capacity was evaluated using the Cao, Zhao, and Xiong (2016) method. This method is based on the hydrophobic interactions the between basic and aromatic amino acid residues of proteins and the anionic form of the well-known stain Coomassie Brilliant Blue G-250 (CCBG) which forms a complex which can be measured at $585 \mathrm{~nm}$. Briefly, $1.2 \mathrm{~mL}$ of a solution of $5 \mathrm{mg} / \mathrm{mL}$ protein in $20 \mathrm{mM}$ phosphate buffer at $\mathrm{pH} 6.0$ were mixed with $300 \mu \mathrm{l}$ of a $0.1 \mathrm{mg} /$ $\mathrm{mL}$ solution CBBG in ultra-pure water. A control was prepared by mixing $1.2 \mathrm{~mL}$ of the phosphate buffer with $300 \mu \mathrm{l}$ of the CCBG solution. Samples were stirred at $2000 \mathrm{rpm}$ for $3 \mathrm{~min}$ using a multi shaker (Heidolph Multi Reax, Heidolph Instruments GmbH \& CO, Schwabach, Germany) and after, centrifuged at $2000 \mathrm{~g}$ for $10 \mathrm{~min}$ at $4^{\circ} \mathrm{C}$ in a Hettich Rotanta 460R centrifuge. The supernatant was taken and centrifuged again under the same conditions. Finally, the absorbance of the supernatant was measured at $585 \mathrm{~nm}$ using a ND-100 Nanodrop Spectrophotometer. The amount of CBBG bound was calculated using the following formula:

CCBG bound $(\mu \mathrm{g})=30 \mu \mathrm{g} * \frac{\left(A b s_{\text {control }}-A b s_{\text {sample }}\right)}{A b s_{\text {control }}}$

\subsection{Statistical analysis}

Analysis of variance (ANOVA) of dependent variables was carried out using Minitab 17.1.0 (Minitab Inc.). Statistics were calculated using a general linear model (GLM) considering the entire variable as fixed factors. Tukey's multiple comparison was calculated to study the effect of the plasma treatment on the functional properties. Experiments were performed in duplicate and analyses were carried out in triplicate.

\section{Results and discussion}

\subsection{Solubility}

Protein solubility depends on both protein characteristics (amino acid sequence, crosslinking, aggregate state and protein structure) and external factors ( $\mathrm{pH}$, temperature, ionic strength). For example, proteins are characterised to be zwitterion, i.e., they have net charge at a specific $\mathrm{pH}$, which is called the isoelectric point (pI). However, outside of this $\mathrm{pH}$ value, their functional groups can change their individual charge leading to a modification of the net charge of the whole protein and consequently, this phenomenon can affect its solubility. Proteins with an open structure, presenting a large charged surface area have better solvation ability and thus, improved solubility. Solubility assessment is important in determining the potential applications of proteins as food ingredients.

The solubility of both haemoglobin and ELP after treatment is compared with controls at different $\mathrm{pH}$ values, ranging from 3 to 8 (Fig. 1). It was found that there is a significant $(p<0.05)$ solubility decrease of haemoglobin at $\mathrm{pH} 4,5$ and 6 after plasma treatment (Fig.1a). However, the treatment increases the solubility significantly at pH 3 ( $p>0.05)$. Finally, no significant differences were found between the control and the treated samples at $\mathrm{pH} 7$ and 8. Regarding the solubility of ELP, it was affected by the treatment, with a decrease in solubility observed $(p<0.05)$ at $\mathrm{pH} 3,4$ and 6 . On the other hand, no effect was found for the other $\mathrm{pH}$ values studied: 5,7 and 8 . These different behaviours, based on the solution $\mathrm{pH}$, might be explained because at $\mathrm{pH}$ values far from the physiological $\mathrm{pH}$ more dramatic changes on the protein structure can occur and thus increase the effect of plasma on the surface hydrophobicity, increasing solubility at acidic pHs. Such analysis could not be performed for the pork gelatin, as the powder could not be dispersed to form a gel.

From these results, it can be observed that plasma tends to decrease the solubility of proteins. This could be due to a modification of the 
A)

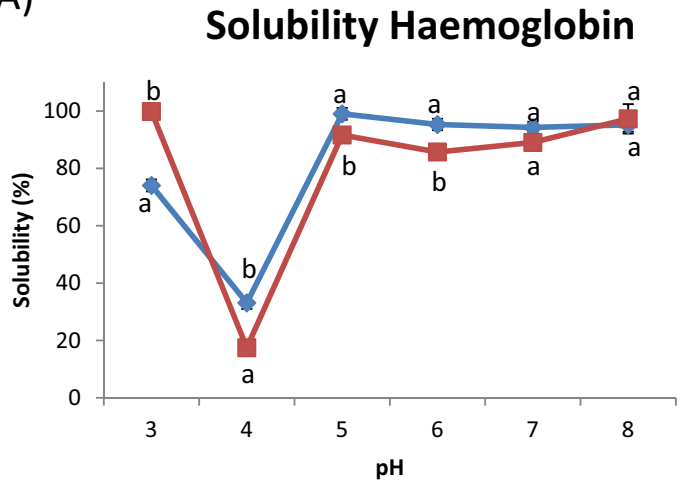

B)

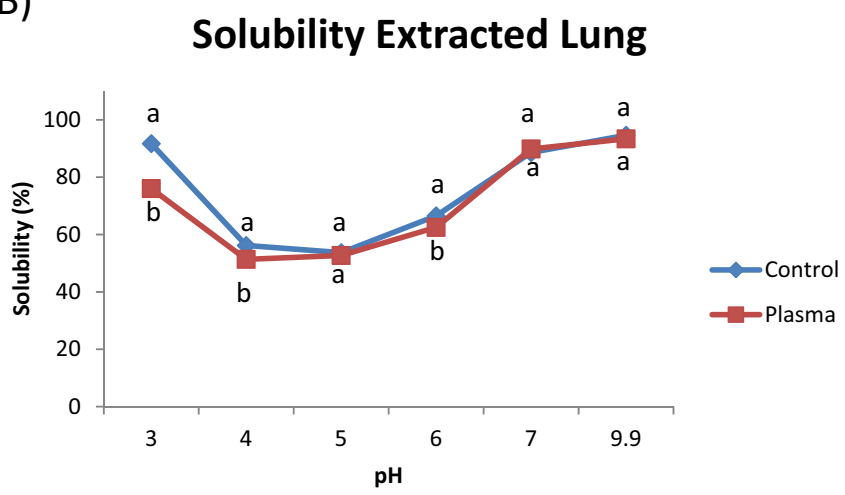

Fig. 1. Solubility results for haemoglobin (A) and ELP protein (B). Different letters indicate a significant difference $(p<0.05)$ for solubility at specific $\mathrm{pH}$ value.

protein surface, exposing more hydrophobic groups which hinder the interaction with water. It has been suggested that cold atmospheric air plasma could cause crosslinking of proteins (Pankaj et al., 2014); which is one of the factors which modifies protein solubility. This is in agreement with the results observed here; due to the formation of aggregates after CAP treatment. Other researchers have reported modifications on the secondary structure of haemoglobin and myoglobin after treatment using a jet plasma using different working gases such as argon, argon with nitrogen as well as argon with oxygen both mixtures at different ratios (Park et al., 2016). These researchers found that there were modifications of the secondary structures, resulting in a decrease of the $\alpha$-helical conformation and an increase of $\beta$-sheet structures; which may have an effect on protein solubility. The effect of plasma on the solubility of other proteins has already been reported. For instance, Bußler et al. (2016) reported that the solubility of proteins extracted from Tenebrio molitor flour decreased after air cold plasma treatment. It is known that plasma can induce oxidation mechanisms (Perez-Andres et al., 2018), and moreover, it is suggested that high levels of oxidation can result in protein denaturation and precipitation, which is associated with decreased protein solubility (Zhang, Xiao, \& Ahn, 2013). Conversely, it was observed that the solubility of pea protein isolate, just after treatment (air as working gas, frequency of $3.0 \mathrm{kHz}$ and voltage of $8.8 \mathrm{kV}$ ) was increased when compared to the control; however, over storage time, the solubility decreased faster in the treated samples (Bußler, Steins, Ehlbeck, \& Schlüter, 2015). Similar results were found by Ji et al. (2018), who observed that CAP improved the solubility of peanut protein after a $1 \mathrm{~min}$ treatment at $35 \mathrm{kV}$ using a similar source system.

\subsection{Emulsifying capacity}

The emulsification capacity of a specific protein depends
A)

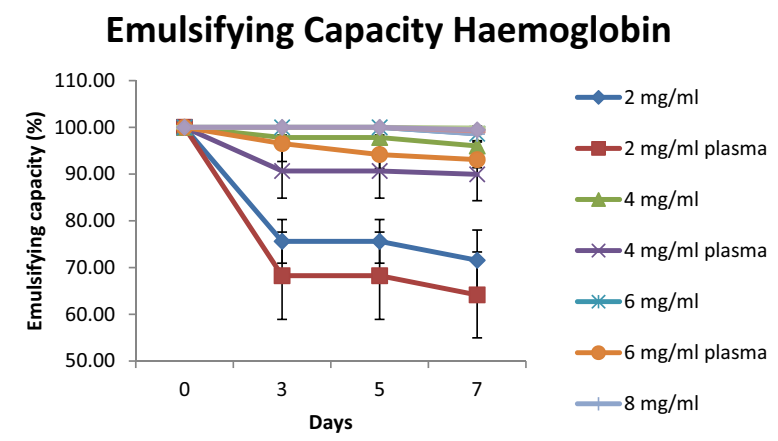

B)

\section{Emulsifying Capacity Pork Gelatin}

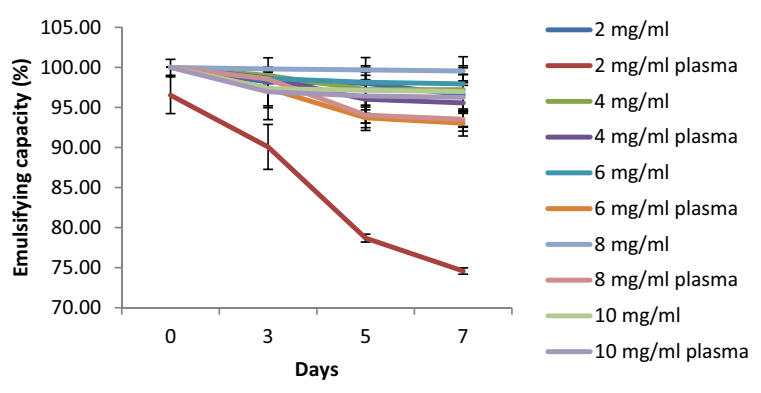

C)

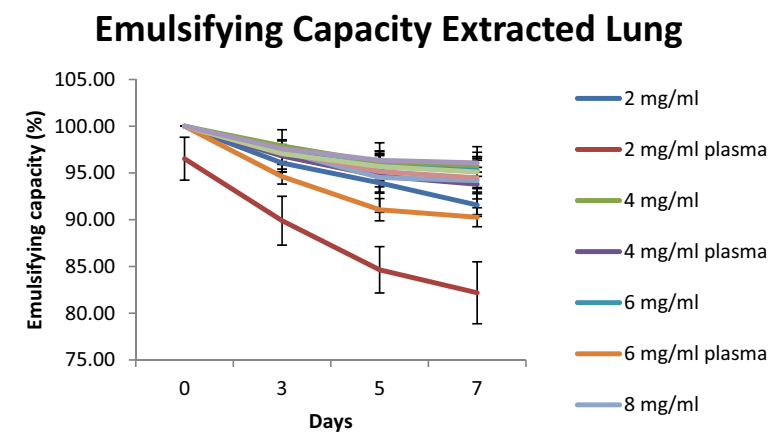

Fig. 2. Emulsifying capacity and stability results for haemoglobin (A, pork gelatin (B) ELP protein (C).

fundamentally on its structure, and the location of the hydrophobic and hydrophilic amino acid groups, i.e., their amphipathic character. An emulsion, a mixture of two immiscible liquids (for example water and oil), is not stable by nature and trends to separate spontaneously into two phases. A protein with a good emulsifying capacity is able to stabilize the mixture, impeding phase separation. Some proteins are used as emulsifiers to stabilize foods such as salad dressings, sauces and mayonnaise.

It was observed that CAP treatment reduced significantly $(p<0.05)$ the emulsifying capacity of the three proteins studied (Fig. 2). Firstly, focusing on haemoglobin, the statistical analysis indicated that the emulsifying ability decreased $(p<0.05)$ at haemoglobin concentrations of $2 \mathrm{mg} / \mathrm{mL}$ and $4 \mathrm{mg} / \mathrm{mL}$ after treatment, however, this effect was not observed at higher concentrations. On the other hand, the emulsification stability showed no differences between the control and the treated samples $(p<0.05)$ for any of the concentrations employed. In the case of pork gelatin, the emulsifying capacity was lower for the untreated samples at 2,6 and $8 \mathrm{mg} / \mathrm{mL}$ $(p<0.05)$. It was found that stability for both treated and control samples decreased over time; however, only from days 5 and 7 , where the treated samples performed significantly worse than the control samples $(p<0.05)$. Finally, the modification of this functional 
property was also studied in ELP, which was similar to that described for haemoglobin and gelatin. The emulsifying capacity was significantly lower $(p<0.05)$ for protein concentrations of 2 and $6 \mathrm{mg} / \mathrm{mL}$. In addition, the emulsion was not stable during the experimental period, and the stability was significantly lower for the plasma treated samples after 3,5 and 7 days.

As mentioned in the previous section, CAP may cause protein aggregation and changes in the protein structure. Both factors together may have an effect on the emulsifying properties. An increase in the particle size, due to aggregation of the protein, generates a new organisation of the different protein groups. The hydrophilic groups would consequently be exposed on the surface, covering the hydrophobic groups located in the inner part, which could not further interact with the non-polar phase of the emulsion. As a result, the amphipathic character of the protein decreases and its emulsifying capacity and stability are negatively affected. However, at higher concentrations the effect of the treatment was not that obvious due to the presence of sufficient hydrophobic groups forming an emulsion. To the best of our knowledge, no other studies regarding the emulsifying ability of proteins after CAP treatment have been reported.

\subsection{Rheology gelling properties}

The impact of CAP on the gelling and rheological properties of the proteins investigated is summarised in Table 1. CAP significantly decreased $(p<0.05)$ the gelation temperature of pork gelatine and ELP. This could be due to the treatment leading to a partial denaturalisation of these proteins, and subsequently, lower temperatures are required to initially unfold the proteins. This modification could help the formation of gels at lower temperatures, because less energy is needed to initiate the protein denaturation, and might be beneficial for specific food products. In contrast, the melting temperature of pork gelatin was not affected by the treatment, since proteins forming the gel are already denaturised and the effect of CAP is masked by the previous thermal treatment to form the gel. In another study, atmospheric air plasma changed the elastic and viscous modulus of dough, suggesting that the radical species formed during the treatment could modify the protein structure, leading to the modification of the rheological properties observed (Segat, Misra, Cullen, \& Innocente, 2015).

\subsection{Water \& oil holding capacity}

The water and oil holding capacity is the ability of a protein to adsorb oil/water inside its structure. For food products, such capacity prevents fluid leakage during food processing or storage. For instance, the water-holding capacity (WHC) affects the tenderness and juiciness of meat and fish products. Higher water and oil capacity leads to better cooking yields, since lower amounts of water or oil are lost. For this reason, both parameters are important factors in the characterization of the functional properties of food proteins, particularly when intended to be used in meat products. The effect of CAP on the water and oil capacity of the proteins studied is reported in Tables 2 and 3.

CAP treatment significantly improved $(p<0.05)$ the water holding

Table 1

Results of gelling and rheological properties. Different letters indicate a significant difference $(p<0.05)$ for between control and treated for a specific protein.

\begin{tabular}{lccc}
\hline & LGC $(\%)$ & T gel $\left({ }^{\circ} \mathrm{C}\right)$ & T mel $\left({ }^{\circ} \mathrm{C}\right)$ \\
\hline Haemoglobin & 4 & $65.30 \pm 0.70^{\mathrm{a}}$ & - \\
Haemoglobin plasma & 4 & $63.23 \pm 1.46^{\mathrm{a}}$ & - \\
Pork gelatin & 2 & $79.33 \pm 1.11^{\mathrm{a}}$ & $35.68 \pm 1.05^{\mathrm{b}}$ \\
Pork gelatin plasma & 3 & $68.5 \pm 4.91^{\mathrm{b}}$ & $34.90 \pm 1.57^{\mathrm{b}}$ \\
ELP & 12 & $60.53 \pm 0.21^{\mathrm{a}}$ & - \\
ELP plasma & 12 & $51.83 \pm 3.12^{\mathrm{b}}$ & - \\
\hline
\end{tabular}

Table 2

Results of water holding capacity. Different letters indicate a significant difference $(p<0.05)$ for between control and treated for a specific protein.

\begin{tabular}{llcc}
\hline & Haemoglobin & Pork gelatin & Extracted lung proteins \\
\cline { 2 - 4 } & (g water/g protein) & (g water/g protein) & (g water/g protein) \\
\hline Control & N/D & $5.36 \pm 0.11^{\mathrm{a}}$ & $4.41 \pm 0.03^{\mathrm{a}}$ \\
Plasma & N/D & $6.10 \pm 0.44^{\mathrm{b}}$ & $4.56 \pm 0.05^{\mathrm{b}}$ \\
\hline
\end{tabular}

N/D: it was not determined because haemoglobin was completely soluble under the experimental conditions.

Table 3

Results of oil holding capacity. Different letters indicate a significant difference $(p<0.05)$ for between control and treated for a specific protein.

\begin{tabular}{llll}
\hline & Haemoglobin & Pork gelatin & Extracted lung proteins \\
\cline { 2 - 4 } & (g oil/g protein) & (g oil/g protein) & (g oil/g protein) \\
\hline Control & $2.98 \pm 0.02^{\mathrm{a}}$ & $1.75 \pm 0.13^{\mathrm{a}}$ & $2.82 \pm 0.09^{\mathrm{a}}$ \\
Plasma & $3.03 \pm 0.06^{\mathrm{a}}$ & $1.55 \pm 0.07^{\mathrm{a}}$ & $4.57 \pm 0.06^{\mathrm{b}}$ \\
\hline
\end{tabular}

capacity of both pork gelatin and ELP, suggesting a partial denaturalisation of the proteins present in these samples. CAP, as previously discussed, can lead to protein unfolding, allowing water molecules to interact with more hydrophilic groups found deeper within the structure, increasing their availability for interaction. On the other hand, there was no impact on the oil holding capacity of the haemoglobin or pork gelatin after $80 \mathrm{kV}$ treatment, for $15 \mathrm{~min}$. However, in the specific case of ELP, the OHC was significantly improved after the treatment compared to the control. ELP is composed of a blend of different types of proteins, and CAP may affect each one differently; thus, some may increase the exposure of hydrophilic groups, while others could expose more hydrophobic groups. This could explain why both WHC and OHC have been increased for this particular sample.

The water and oil holding capacity of pea testa flour was reported to be improved after $10 \mathrm{~min}$ treatment at a frequency of $3.0 \mathrm{kHz}$ and a voltage of $8.8 \mathrm{kV}$, using a surface dielectric-barrier air-discharge system (Bußler et al., 2015). These authors reported that plasma induced modifications of the protein composition and structure observed with changes in the fluorescence emission spectra. In contrast, when the same plasma system and conditions were applied to an insect flour, it was found that the water holding capacity significantly decreased after treatment, regardless of processing time (from 1 to $15 \mathrm{~min}$ ) (Bußler et al., 2016). The OHC in these samples was affected by the treatment; however, treatment time was not significantly correlated.

\subsection{Surface hydrophobicity}

To correlate the changes observed in the functional properties with modifications of the protein structure, the hydrophobicity of the samples was determined. An increment in this parameter is indicative of protein unfolding and subsequent exposure of hydrophobic residues. Statistical analysis showed that there were not any significant differences $(p>0.05)$ between the control and treated samples for both pork gelatin and ELP, as reported in Fig. 3. However, in the case of haemoglobin the hydrophobicity surface increased significantly $(p<0.05)$ with plasma treatment. The radical species generated by CAP treatment may disrupt the native haemoglobin conformation, unfolding the protein and exposing these non-polar groups, leading to an increase of the surface hydrophobicity. Haemoglobin has a high content of hydrophobic amino acids, and minor changes in their structure will lead to changes in hydrophobicity. However, gelatin is already a partially hydrolysed protein, and its structure is already compromised, so surface hydrophobicity effects will be less relevant after CAP treatment, in terms of structural changes. Finally, the ELP powder, as previously 


\section{Surface Hydrophobicity}

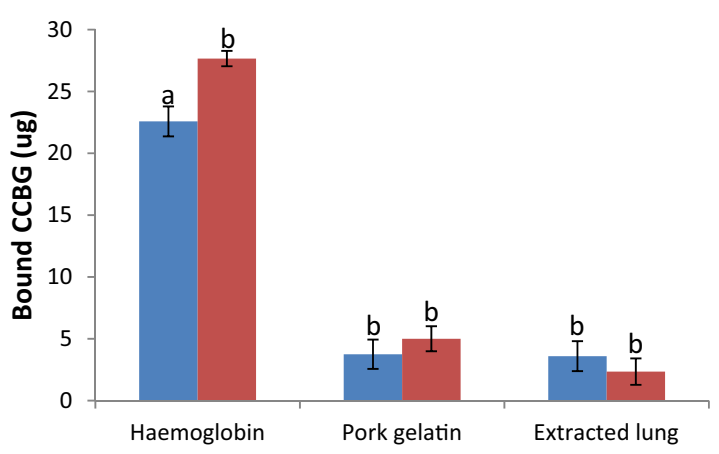

Fig. 3. Surface hydrophobicity results of control and treated samples for haemoglobin, pork gelatin and extracted lung proteins. Different letters indicate a significant difference $(p<0.05)$ for hydrophobic surface between control and treated for a specific protein.

described, is a blend of many different proteins, so changes in its structure may not lead to an appreciable modification of its hydrophobicity, because a balancing effect may occur.

These results agree with those reported by (Segat et al., 2015). These authors applied CAP, using atmospheric air, on solutions of whey protein isolate at $2 \%(\mathrm{w} / \mathrm{v})$ in phosphate buffer $(50 \mathrm{Mm}, \mathrm{pH} 6.8)$, finding a modification of its structure, leading to an increase of the surface hydrophobicity. A modification of the secondary structure and hydrophobicity surface of peanut protein by cold plasma was also reported using argon, as well argon mixed with oxygen or nitrogen at different ratios as working gases (Ji et al., 2018). It was observed that the surface hydrophobicity decreased linearly after 1, 2, 3 and 4 min. Similar trends were found for the $-\mathrm{SH}$ groups but an increase was highlighted after $4 \mathrm{~min}$ of treatment. Plasma discharges can lead to etching, cross-linking of proteins and oxidative reactions that can change the structure of proteins. One such modification is the exposition of the inner - $\mathrm{SH}$ groups, which can be oxidised to form disulphide bonds, which subsequently can be disrupted to free $-\mathrm{SH}$. (Takai et al., 2014) suggested that the formation of disulphide bonds and cleavage could happen concurrently.

\section{Conclusions}

Depending of the native structure and nature of the protein, CAP treatment affected the functional properties in different ways. The findings point to the specific nature of plasma-protein interactions and the need for individual proteins to be studied as a function of plasma conditions. These changes could be beneficial or detrimental depending on the features desired. For instance, the solubility of the proteins extracted from the bovine lung protein decreased significantly after treatment, while its oil holding capacity had a significant improvement. Thus, treated lung proteins could be employed in meat products, where oil holding capacity is more important than solubility. Changes in the functional properties could not be related to the observed changes in hydrophobicity, meaning that other effects such as oxidation or crosslinking might have a more relevant role than that of protein unfolding. From this research, it can be concluded that CAP has potential applications in modifying protein-based food ingredients, increasing the applicability of novel protein sources alongside those currently used. Depending on the requirements of a specific product, a food protein could be treated to achieve specific properties and behaviours. However, further research should be carried out to optimise CAP parameters for specific food proteins.

\section{Acknowledgments}

The work on this paper is supported by a project that has received funding from the European Union's Horizon 2020 Spreading Excellence and Widening Participation programme under Grant Agreement No. 692276.

\section{Declaration of Competing Interest}

The authors declare no conflict of interest.

\section{References}

Álvarez, C., Drummond, L., \& Mullen, A. M. (2018). Expanding the industrial applications of a meat co-product: Generation of low-haemoglobin content plasma by means of red cells crenation. Journal of Cleaner Production, 185, 805-813.

Alves, L. D., da Silva, M. S., Flores, D. R. M., Athayde, D. R., Ruviaro, A. R., Brum, D. D., .. Cichoski, A. J. (2018). Effect of ultrasound on the physicochemical and microbiological characteristics of Italian salami. Food Research International, 106, 363-373.

Amiri, A., Sharifian, P., \& Soltanizadeh, N. (2018). Application of ultrasound treatment for improving the physicochemical, functional and rheological properties of myofibrillar proteins. International Journal of Biological Macromolecules, 111, 139-147.

Arvanitoyannis, I. S., Kotsanopoulos, K. V., \& Savva, A. G. (2017). Use of ultrasounds in the food industry-methods and effects on quality, safety, and organoleptic characteristics of foods: A review. Critical Reviews in Food Science and Nutrition, 57(1), $109-128$.

Awuah, G., Ramaswamy, H., \& Economides, A. (2007). Thermal processing and quality: Principles and overview. Chemical Engineering and Processing: Process Intensification, 46(6), 584-602.

Barba, F. J., Parniakov, O., Pereira, S. A., Wiktor, A., Grimi, N., Boussetta, N., ... WitrowaRajchert, D. (2015). Current applications and new opportunities for the use of pulsed electric fields in food science and industry. Food Research International, 77, 773-798.

Beuchat, L. R. (1977). Functional and electrophoretic characteristics of succinylated peanut flour protein. Journal of Agricultural and Food Chemistry, 25(2), 258-261.

Bourke, P., Ziuzina, D., Boehm, D., Cullen, P. J., \& Keener, K. (2018). The potential of cold plasma for safe and sustainable food production. Trends in Biotechnology, 36(6), 615-626.

Bußler, S., Rumpold, B. A., Fröhling, A., Jander, E., Rawel, H. M., \& Schlüter, O. K. (2016). Cold atmospheric pressure plasma processing of insect flour from Tenebrio molitor: Impact on microbial load and quality attributes in comparison to dry heat treatment. Innovative Food Science \& Emerging Technologies, 36, 277-286.

Bußler, S., Steins, V., Ehlbeck, J., \& Schlüter, O. (2015). Impact of thermal treatment versus cold atmospheric plasma processing on the techno-functional protein properties from Pisum sativum 'Salamanca'. Journal of Food Engineering, 167, 166-174.

Cao, Y., Zhao, J., \& Xiong, Y. L. (2016). Coomassie brilliant blue-binding: A simple and effective method for the determination of water-insoluble protein surface hydrophobicity. Analytical Methods, 8(4), 790-795.

Coffmann, C., \& Garciaj, V. (1977). Functional properties and amino acid content of a protein isolate from mung bean flour. International Journal of Food Science \& Technology, 12(5), 473-484.

Cullen, P., \& Norton, T. (2012). 10 ozone sanitisation in the food industry. Ozone in food processing (pp. 163).

Gavahian, M., Chu, Y. H., Khaneghah, A. M., Barba, F. J., \& Misra, N. N. (2018). A critical analysis of the cold plasma induced lipid oxidation in foods. Trends in Food Science \& Technology, 77, 32-41.

Giteru, S. G., Oey, I., \& Ali, M. A. (2017). Feasibility of using pulsed electric fields to modify biomacromolecules: A review. Trends in Food Science \& Technology, 72, 91-113.

Guyon, C., Le Vessel, V., Meynier, A., \& de Lamballerie, M. (2018). Modifications of protein-related compounds of beef minced meat treated by high pressure. Meat Science, 142, 32-37.

Huang, H.-W., Wu, S.-J., Lu, J.-K., Shyu, Y.-T., \& Wang, C.-Y. (2017). Current status and future trends of high-pressure processing in food industry. Food Control, 72, 1-8.

Inklaar, P. A., \& Fortuin, J. (1969). Determining the emulsifying and emulsion stabilizing capacity of protein meat additives. Food Technology, 23, 103-107.

Ji, H., Dong, S., Han, F., Li, Y. T., Chen, G. Y., Li, L., \& Chen, Y. (2018). Effects of dielectric barrier discharge (DBD) cold plasma treatment on physicochemical and functional properties of peanut protein. Food and Bioprocess Technology, 11(2), 344-354.

Kang, D. C., Zou, Y. H., Cheng, Y. P., Xing, L. J., Zhou, G. H., \& Zhang, W. G. (2016). Effects of power ultrasound on oxidation and structure of beef proteins during curing processing. Ultrasonics Sonochemistry, 33, 47-53.

Kramer, A., Bekeschus, S., Matthes, R., Bender, C., Stope, M. B., Napp, M., ... Schauer, F. (2015). Cold physical plasmas in the field of hygiene-relevance, significance, and future applications. Plasma Processes and Polymers, 12(12), 1410-1422.

Kristo, E.a. C. M. (2015). Functional properties of food proteins. Applied food protein chemistry.

Lamsal, B., Jung, S., \& Johnson, L. (2007). Rheological properties of soy protein hydrolysates obtained from limited enzymatic hydrolysis. Lwt-Food Science and Technology, 40(7), 1215-1223.

Li, X., \& Farid, M. (2016). A review on recent development in non-conventional food sterilization technologies. Journal of Food Engineering, 182, 33-45.

Li, Y., Chen, Z., \& Mo, H. (2007). Effects of pulsed electric fields on physicochemical 
properties of soybean protein isolates. LWT - Food Science and Technology, 40(7), $1167-1175$.

Liu, R., Liu, Q., Xiong, S. B., Fu, Y. C., \& Chen, L. (2017). Effects of high intensity ultrasound on structural and physicochemical properties of myosin from silver carp. Ultrasonics Sonochemistry, 37, 150-157.

Lynch, S. A., Álvarez, C., O'Neill, E. E., Keenan, D. F., \& Mullen, A. M. (2018) Optimization of protein recovery from bovine lung by $\mathrm{pH}$ shift process using response surface methodology. Journal of the Science of Food and Agriculture, 98(5), 1951-1960.

Mirmoghtadaie, L., Aliabadi, S. S., \& Hosseini, S. M. (2016). Recent approaches in physical modification of protein functionality. Food Chemistry, 199, 619-627.

Nazari, B., Mohammadifar, M. A., Shojaee-Aliabadi, S., Feizollahi, E., \& Mirmoghtadaie, L. (2018). Effect of ultrasound treatments on functional properties and structure of millet protein concentrate. Ultrasonics Sonochemistry, 41, 382-388.

O'sullivan, J. J., Park, M., Beevers, J., Greenwood, R. W., \& Norton, I. T. (2017). Applications of ultrasound for the functional modification of proteins and nanoemulsion formation: A review. Food Hydrocolloids, 71, 299-310.

Pankaj, S. K., Bueno-Ferrer, C., Misra, N. N., Milosavljević, V., O'Donnell, C. P., Bourke, P., ... Cullen, P. J. (2014). Applications of cold plasma technology in food packaging. Trends in Food Science \& Technology, 35(1), 5-17.

Pankaj, S. K., Misra, N. N., \& Cullen, P. J. (2013). Kinetics of tomato peroxidase inactivation by atmospheric pressure cold plasma based on dielectric barrier discharge. Innovative Food Science \& Emerging Technologies, 19, 153-157.

Pankaj, S. K., Wan, Z. F., \& Keener, K. M. (2018). Effects of cold plasma on food quality: A review. Foods, 7(1), 21.

Park, J. H., Kim, M., Shiratani, M., Cho, A. E., Choi, E. H., \& Attri, P. (2016). Variation in structure of proteins by adjusting reactive oxygen and nitrogen species generated from dielectric barrier discharge jet. Scientific Reports, 6, 14.

Penteado, M., Lajolo, F. M., \& Pereiradossantos, N. (1979). Functional and nutritional properties of isolated bovine blood proteins. Journal of the Science of Food and Agriculture, 30(8), 809-815.

Perez-Andres, J. M., Charoux, C. M. G., Cullen, P. J., \& Tiwari, B. K. (2018). Chemical modifications of lipids and proteins by nonthermal food processing technologies. Journal of Agricultural and Food Chemistry, 66(20), 5041-5054.

Rodriguez-Gonzalez, O., Buckow, R., Koutchma, T., \& Balasubramaniam, V. (2015).
Energy requirements for alternative food processing technologies-Principles, assumptions, and evaluation of efficiency. Comprehensive Reviews in Food Science and Food Safety, 14(5), 536-554.

Saricaoglu, F. T., Gul, O., Besir, A., \& Atalar, I. (2018). Effect of high pressure homogenization (HPH) on functional and rheological properties of hazelnut meal proteins obtained from hazelnut oil industry by-products. Journal of Food Engineering, 233, 98-108.

Segat, A., Misra, N. N., Cullen, P. J., \& Innocente, N. (2015). Atmospheric pressure cold plasma (ACP) treatment of whey protein isolate model solution. Innovative Food Science \& Emerging Technologies, 29, 247-254.

Takai, E., Kitamura, T., Kuwabara, J., Ikawa, S., Yoshizawa, S., Shiraki, K., ... Kitano, K. (2014). Chemical modification of amino acids by atmospheric-pressure cold plasma in aqueous solution. Journal of Physics D-Applied Physics, 47(28), 15.

Tolouie, H., Mohammadifar, M. A., Ghomi, H., \& Hashemi, M. (2017). Cold atmospheric plasma manipulation of proteins in food systems. Critical Reviews in Food Science and Nutrition, 1-15.

Villamonte, G., Pottier, L., \& de Lamballerie, M. (2016). Influence of high-pressure processing on the physicochemical and the emulsifying properties of sarcoplasmic proteins from hake (Merluccius merluccius). European Food Research and Technology, 242(5), 667-675.

Wu, L., Zhao, W., Yang, R. J., \& Chen, X. C. (2014). Effects of pulsed electric fields processing on stability of egg white proteins. Journal of Food Engineering, 139, 13-18.

Xuan, X. T., Cui, Y., Lin, X. D., Yu, J. F., Liao, X. J., Ling, J. G., \& Shang, H. T. (2018). Impact of high hydrostatic pressure on the shelling efficacy, physicochemical properties, and microstructure of fresh razor clam (Sinonovacula constricta). Journal of Food Science, 83(2), 284-293.

Yang, J., Liu, G., Zeng, H., \& Chen, L. (2018). Effects of high pressure homogenization on faba bean protein aggregation in relation to solubility and interfacial properties. Food Hydrocolloids, 83, 275-286.

Yang, J., \& Powers, J. R. (2016). Effects of high pressure on food proteins. High pressure processing of food (pp. 353-389). Springer.

Zhang, W. G., Xiao, S., \& Ahn, D. U. (2013). Protein oxidation: Basic principles and implications for meat quality. Critical Reviews in Food Science and Nutrition, 53(11), 1191-1201. 